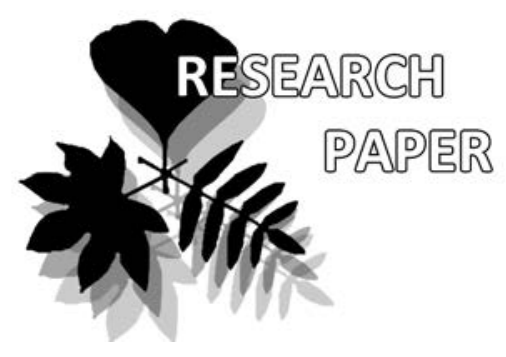

Andrey N. Efremov ${ }^{1 *}$

e-mail: stratiotes@yandex.ru

Veronika S. Grishina ${ }^{2}$

e-mail: nika.grishina2011@yandex.ru

Dmitry E. Kislov

e-mail: kislov@easydan.com

Attila Mesterházy ${ }^{4}$

e-mail: amesterhazy@gmail.com

Cezary Toma

e-mail: cezarytoma@poczta.onet.pl

${ }^{1}$ Research Center of Fundamental and Applied Problems of Bioecology and Biotechnology of Ulyanovsk State Pedagogical University, Ulyanovsk, Russia

${ }^{2}$ Omsk State Pedagogical University, Omsk, Russia

3 Botanical Garden-Institute FEB RAS, Vladivostok, Russia

${ }^{4}$ Directorate of Hortobágy National Park, Hungary

${ }^{2}$ Kazimierz Wielki University, Bydgoszcz, Poland

* corresponding author

Manuscript received: 22.02 .2020

Review completed: 02.10 .2020

Accepted for publication: 28.10.2020

Published online: 02.11 .2020

\section{The genus Hydrocharis L. (Hydrocharitaceae): distribution features and conservation status}

Andrey N. Efremov ${ }^{1}$, Veronika S. Grishina ${ }^{2}$, Dmitry E. Kislov ${ }^{3}$, Attila Mesterházy ${ }^{4} \&$ Cezary Toma ${ }^{5}$

\begin{abstract}
A B S T R A C T
The genus Hydrocharis L. includes three geographically isolated species. Analysis of the actual data (32 thousand geographical locations and 1946 herbarium sheets) covering the period 1765-2019 made it possible to clarify the nature of the distribution of these species and its changes. Hydrocharis morsus-ranae L. has disjunctive Eurasian - North American temperate range, with a massive North American enclave, the formation of which began in the 1930-1940s. The range of Hydrocharis dubia (Blume) Backer is disjunctive Southeast Asian - Australian subboreal-tropical, Australia enclave began forming in the 1850-1870s. Hydrocharis chevalieri (De Wild.) Dandy is a macrothermal Central African equatorial endemic. Current threat status of all species may be estimated as Least Concern. The mean annual temperature is the most contrasting feature of the distribution areas of the species, water depth, bottom soil type and hydrochemical composition have lower impact. Prognostic models of the potential distribution of the tagged species have been made. K e y w o r d s : Hydrocharis, Hydrocharitaceae, range, protection status, ecology, invasion
\end{abstract}

\section{P E 3 Ю M E}

Ефремов А.Н., Гришина В.С., Кислов А.Е., Местерхази А., Тома Ц. РоА Hydrocharis L. (Hydrocharitaceae): особенности распространения и статус охраны. РОА Hydrocharis L. включает три географически изолированных вила. Анализ фактических данных (32 тыс. географических мокаций и 1946 гербарных Аистов), охватывающих период 1765-2019 гг., позволил выяснить характер распространения этих видов и его изменения. Hydrocharis morsus-ranae L. имеет Аизъюнктивный евразийско-североамериканский умеренный ареац, формирование крупного анклава в Северной Америке началось в 1930-1940-е годЫ. Apeas Hydrocharis dubia (Blume) Backer явАяется Аизъюнктивным юговосточноазиатско-австралийским суббореально-тропическим, австралийский анклав начал формироваться в 1850-1870-х годах. Hydrocharis chevalieri (De Wild.) Dandy - макротермальный экваториальный энАемик Центральной Африки. Современный охранный статус всех видов можно оценить как не вызывающий опасения. Среднегодовая температура является наиболее контрастной особенностью районов распространения вида, глубина воды, тип донного грунта и гидрохимический состав имеют меньшее значение. Построены прогностические модели потенциаАьного распространения исследуемых видов. КАючевые слова: Hydrocharis, Hydrocharitaceae, ареац, статус охраны, экология, инвазия
The genera Hydrocharis L. and Limnobium Rich., united in the subfamily Hydrocharitoideae, diverged from the main part of the family Hydrocharitaceae in the Miocene (Chen et al. 2012). The genus Hydrocharis includes three geographically isolated species: Hydrocharis chevalieri (De Wild.) Dandy, H. dubia (Blume) Backer and H. morsus-ranae L. (Cook \& Lüönd 1982). Hydrocharis dubia and H. morsus-ranae have formed extensive secondary ranges, causing significant damage to local ecosystems (Cook \& Lüönd 1982, Bean 2011). On the other hand, $H$. morsus-ranae has declined or has been extirpated and it is considered a conservation concern in several areas (e.g. South and Western Europe, Western Asia). Hydrocharis chevalieri is a Central African endemic, morphologically and ecologically significantly distinguished from other species. All species of the genus can be dominant or subdominant in the formation of aquatic vegetation (Cook \& Lüönd 1982, Lubini 1983).
The purpose of this study is to clarify features of the genus Hydrocharis distribution in the world. The solution to this problem required the implementation of the following main tasks: (a) to thoroughly analyze the relevant information and known locations of the species of the genus Hydrocharis in the world, (b) to determine basic environmental characteristics that can limit the distribution of the species, (c) evaluate the current protection status.

\section{MATERIAL AND METHODS}

The data collection on Hydrocharis distribution was performed by analytical generalization of web (Appendix 1) and published information sources (q.v. Literature Cited), the analysis of herbarium collections (Appendix 2) and the authors' original database (hereinafter "AD"). Due to the specificity of the research, below there are references to the oldest herbarium specimens of the region and references 
covering the widest specimens' geography (Appendix 3). The data includes web sources, records of 1946 herbarium specimens and references covering the period 1765-2019. Web sources were used only if they correspond to the criteria of reliability i.e. not deviating from the known range of the spreading, accompanied by indications of the exact location.

The distribution map, containing over 32 thousand locations, was created using "GBIF occurrences" add-on for QGIS 3 and standard QGIS tools for placing the locations; some of the data was plotted manually. The extent of occurrence (IUCN 2012) was calculated based on the polygons created by joining the outside points on the map that match known locations of the specimens. For computing the area of occupancy (IUCN 2012) we used the sum of areas of water bodies, vector data provided by Natural Earth (2019). The world elevation data was taken from ETOPO1 map (Amante 2009) and basic materials used for global assessment of the distribution of aquatic plants (Murphy et al. 2019).

We extrapolated species distribution data on the entire surface of Earth using standard set of bioclimatic variables (Hijmans et. al 2005). As a supervised learning algorithm, the random forest classifier from Scikit-learn package (Pedregosa 2011) has been applied. We followed the recursive feature elimination with cross-validation procedure RFECV (Pedregosa 2011) to get the best set of features yielding highest accuracy scores. After the RFECV procedure was applied we got three most important features that provided the best prediction accuracy. These are BIO15 (importance $=0.36$ ) - precipitation seasonality (coefficient of variation), BIO3 (importance $=0.35$ ) isothermality (mean diurnal / annual temperature range),
$\mathrm{BIO} 2$ (importance $=0.28)-$ mean diurnal range (mean of monthly, max remperature - min remperature); other features have significantly lower influence on the prediction and were not accounted when creating the map.

The conservation status was determined using methodology proposed by the International Union for Conservation of Nature (IUCN 2012).

\section{RES U LT S}

The description of the Hydrocharis species spreading within the global range can be found further, the map of the present range is shown in Fig. 1.

\section{Distribution of Hydrocharis morsus-ranae}

The modern $H$. morsus-ranae range is disjunctive Eurasian - North American temperate. The main part of the range in Eurasia is from 51 (Asia) and 36 (Europe) to $63-64^{\circ} \mathrm{N}$, with the northern border reaching $69^{\circ} \mathrm{N}$ in Fennoscandia and $66.5^{\circ} \mathrm{N}$ in Western Siberia, and the southern borders reaching $32^{\circ} \mathrm{N}$ in the Arabian Peninsula and northern Africa. The secondary range includes a significant North American enclave between (28) 42 and $48^{\circ} \mathrm{N}$ and small stands in Eurasia (Fig. 1). A more detailed description of the distribution by macroregions is given below.

Hydrocharis morsus-ranae is a sporadically distributed species in the Western Europe, but population sizes are decreasing in certain territories. The plants flower and occasionally bear fruit (e.g. in Britain (Appendix 1: Mountfor 2019)). In the United Kingdom of Great Britain and Ireland it is quite common, but is rare in Scotland. This species has declined in Britain in the last century, but some populations have been reported in canals outside of its native range (Cook \& Lüönd 1982, Preston \& Croft 1997, Appendix 1: Mount-

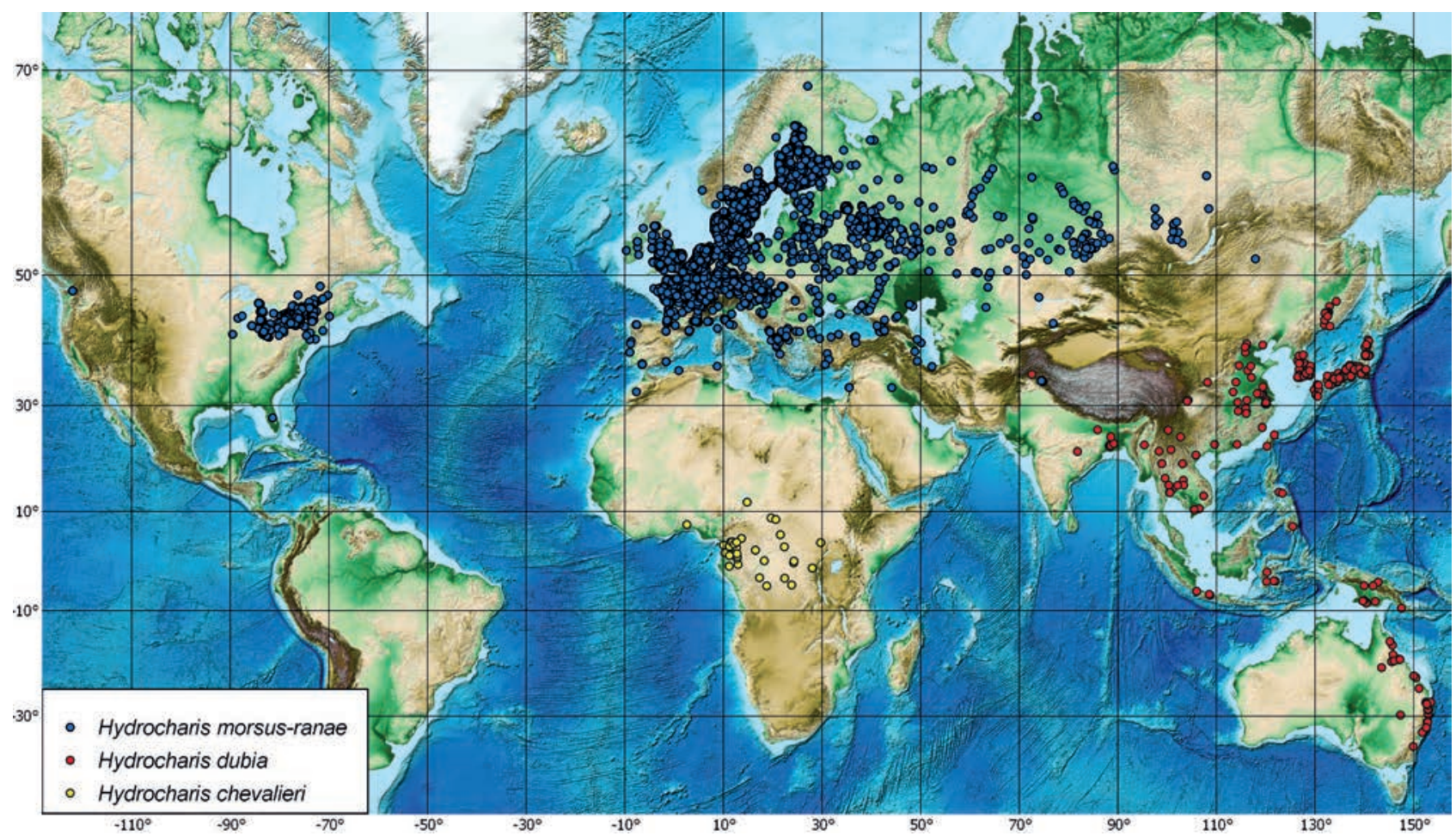

Figure 1 World distribution of the species of Hydrocharis $\mathrm{L}$. 
ford 2019, GBIF 2019, E, W). In France the species is quite common, although it is rare in the south (Appendix 1: Inventaire 2019, GBIF 2019, Z+ZT, W) and is absent from Pyrenees, Massif Central, French Alps. In Belgium and Luxembourg it has disappeared from many previously known habitats (Appendix 1: IUCN 2019, Belgian 2019, $\mathrm{Z}+\mathrm{ZT}, \mathrm{W})$. In the Netherlands H. morsus-ranae is commonly found across the country (Appendix 1: FLORON 2019, IUCN 2019, Invasive 2019, GBIF 2019, Z+ZT, W), and often forms dense thickets.

Hydrocharis morsus-ranae is generally a widespread species, it is rare in mountain areas of the Central Europe. The population sizes are declining and it has disappeared from some areas. On the other hand, the building of reservoirs and increasing eutrophication contribute to the distribution of H. morsus-ranae in secondary habitats. In the Czech Republic H. morsus-ranae occurs mainly in Central and Eastern Bohemia, southern Moravia. It is rare in southwestern and southern Bohemia, North-Eastern Moravia and Silesia and the population sizes show a declining trend. This species has vanished from many of its sites due to habitat destruction or changing (Danihelka et al. 2012, Kaplan 2018, Appendix 1: GBIF 2019, PRC). In Slovakia it is found in the Pannonian region and is extinct in the Carpathians (Turis et al. 2014). In Hungary the plant is quite common in Magyar Középhegység (Transdanubian Mountains, North Hungarian Mountains), Great Hungarian Plain and is rare in Southern Transdanubia (Király 2007, BP). In Poland it is common (Zając \& Zając 2001, Toma 2013). In Germany and Liechtenstein (IUCN 2019) H. morsus-ranae is rare, it is mainly found in the lowlands of north (Western Pomerania, North Rhine-Westphalia, Saxony-Anhalt, Schleswig-Holstein) and Bavaria (Schill \& Krautkrämer 2019, Appendix 1: GBIF 2019). In Austria it occurs in all regions except Tirol and Vorarlberg, however, it is highly endangered (Schill \& Krautkrämer 2019, W, Z+ZT). The species is absolutely protected in the cantons of Thurgau and Waadt in Switzerland (Appendix 1: Info flora 2019, GBIF 2019, W, Z+ZT, LE). It is occasionally found in Slovenia (Borská lowland, Danubian plain, East Slovakian plain) (Martinčič \& Susnik 1969, Kochjarová et al. 2013, Appendix 1: GBIF 2019, LE, BP).

There is a noticeable decrease in the number of known populations and habitats in the Southern Europe. The species is found in the west of Portugal (Beira Litoral, Estremadura, Ribatejo) and in the northeast and south of Spain (Huelva, Gerona, Lugo). The species is endangered in the Iberian Peninsula (Talavera 2010, ILISP, BC, VAL). It is sporadically distributed in the North and Central Italy, in the south it is rare or extinct (Conti 2005, Acta 2007, Appendix 1: GBIF 2019, Invasive 2019, Z+ZT, FI). In Croatia and Serbia it is limited only by the Pannonian Plain (Jankovich 1975, Vukov et al. 2003, Dÿigurski et al. 2010, Nikolić 2015). H. morsus-ranae is rare in Bosnia and Herzegovina (Beck von Mannagetta 1904) and Albania (Shkodra, Ohrid, Prespa Lakes, the Runa River, the Roskovec Swamp) (Barina 2017, W). The species is very rare in North Macedonia (Ohridsko Ezero, Prespansko Ezero, Dojran Ezero, Strumica) (Beck von Mannagetta 1904, Micevski 1969, W) and Montenegro (Skadar Lake) (Pulević 2005). It is rarely found in the continental Greece (North Central Greece, North and South Pindos, North-East Greece, Sterea Ellas) (Dimopoulos 2013; Appendix 1: Vascular 2019) and has not been reported from Crete.

In general, $H$. morsus-ranae is quite common only in the southern parts of the Northern Europe. The plants sometimes flower abundantly and bear fruit; at the northern border vegetative reproduction prevails. The species is often found across Denmark (Hartvig 2005, Appendix 1: GBIF 2019, BP, PR, LE). Hydrocharis has become commoner in Finland in recent times due to eutrophication, the most distribution sites are found in the southern and central parts of the country, it is spread up to Lapland with the northern border at $68.9^{\circ} \mathrm{N} 27.1^{\circ} \mathrm{E}$ (Uotila 2002, Appendix 1: Lampinen \& Lahti 2017, LE, BP, W, Z+ZT). In Sweden it is currently distributed mainly in the south and less so in the central regions (Appendix 1: LifeWatch 2018, W, Z+ZT).

Hydrocharis morsus-ranae is a widespread in the Eastern Europe. It is often found in Belarus (Dubovik 2013, LE, $\mathrm{MW}$ ), common in all regions of Latvia (mainly in the South and South-East) (Birkmane 1953, Appendix 1: GBIF 2019, LE, RIG), Estonia (Lellep 1984, Appendix 1: GBIF 2019, LE, TLM), Lithuania (Pipnys 1963, Appendix 1: GBIF 2019, LE) and Kaliningrad region of Russia (LE). In Ukraine it is distributed unevenly: it is common in Polesye (forest) and forest and steppe zone, in the Ciscarpathian Plain and steppe it occurs sporadically (Dobrochaeva 1987, Dubina 1993, Appendix 1: GBIF 2019, LE, MW). In Romania it is occasionally found across the territory with the exception of the Carpathians (Topa 1966, Z+ZT, W). In Moldova it is reported for the entire territory, but is rare in the Central Moldavian Plateau (Geideman et al. 1986, W, PR). In Bulgaria H. morsus-ranae was previously more widely distributed, it is now occasionally found in the valleys of the Danube, Maritsa and Struma Rivers (Jordanov 1963, BP).

In the North of European Russia the plant is commonly found (Minyaev et al. 1981, Appendix 1: GBIF 2019, LE, MW, IBIW). It is sporadically distributed in Karelia, in the far south (Pryladozhie and Prionezhie) it occurs frequently enough, in the rest of the south it is rare. The most northern locality in the macroregion is $63.5^{\circ} \mathrm{N}$ (Kravchenko 2007). In Central Russia and the Black Soil Zone H. morsus-ranae is widespread, in the Non-Black Soil Zone it occurs somewhat more often (Kamyshev 1978, Gusev 1979, Maevsky 2014, Bulohov \& Vyalichkin 1998, Appendix 1: GBIF 2019, LE, MW, IBIW). In the Upper and Middle Volga it is found frequently and very frequently (Gusev 1979, Papchenkov 2001, Appendix 1: GBIF 2019, LE, MW, IBIW). In the Lower Volga region it is common, but only occasionally found in the Caspian Lowland (Skvortsov 2006, Gusev 1979, Appendix 1: GBIF 2019, LE, MW, IBIW, SARAT, RWBG).

Sporadically distributed in the Caucasus and the Ciscaucasia species, the most numerous habitats are found in the basins of major rivers (Don, Kuban), but it is rare in mountain areas. Hydrocharis morsus-ranae forms dense thickets in eutrophicated water bodies, abundant in irrigation canals and ditches. The species is rare in Georgia (Samegrelo and Upper Svaneti, vicinity of Poti; probably Imereti) and Ab- 
khazia (Gagnidze 2005, LE, ERA, TBI, TGM). The first collections for Azerbaijan are dated the year 1897 (Lenkoran and Astara districts); at present it is probably extinct. It is not known from Armenia (Garielyan \& Oganisyan 2001). In the Southern Russia and the Ciscaucasia the species is distributed irregularly. It is more common in the Western Ciscaucasia and is occasionally found in the Eastern Ciscaucasia, the Western and Eastern Transcaucasia, it is rare in the Western Caucasus (Novosad 1992, Zernov 2006, Ivanov 2019, Shvanova 2006, LE, MW, TGM). In the Crimea Peninsula $H$. morsus-ranae is an introduced species which was found in the 2011 in the vicinity of Sevastopol (Appendix A: All flowers 2019).

Hydrochsris morsus-ranae is quite common in the Ural and the Cis-Ural. In the Middle Urals the species is quite common, though less so in the Northern and Southern Urals (Ovesnov 1997, Ryabinina \& Knyazev 2009, Kulikov 2010, Appendix 1: GBIF 2019, LE, MW, IBIW). The northern border of its distribution lies in the south of the Komi Republic, and thus in the taiga zone (Martynenko \& Gruzdev 2008).

In the Western Siberia and the Altai the plants regularly and abundantly bear fruit, although fruiting in the North is rare. There are numerous paleontological records, the earliest of them are dated Miocene (Nikitin 2006, LEPAL). The species is widespread in Western Siberia; it is sporadically distributed in the Central Ob Lowland, in the south H. morsus-ranae is quite common. The northern border of its distribution almost reaches the Gulf of $\mathrm{Ob}\left(\mathrm{ca} .66^{\circ} \mathrm{N}\right)$ (Dobrokhotova 1956, Timokhina 1988, Appendix 1: GBIF 2019, LE, NS, NSK, TK, PD). In the Altai region it is unevenly distributed, common in the Northwest Altai; occasionally found on the Salair Ridge, rarely on the Western and Northern Altai, Kuznetsk Basin, Kuznetsk Alatau (Timokhina 1988, Ebel 2012, Appendix 1: GBIF 2019, LE, NS, TK).

In the Middle Siberia it is occasionally found in the Upper Yenisei floristic region (the south of Krasnoyarsky Territory) and in the Cisyenissey Sayans (Timokhina 1988, Antipov 2012, Stepanov 2016, LE, NS, TK), the northern distribution border reaches ca. $66.5^{\circ} \mathrm{N}$.

The eastern border of the distribution range in Eastern Siberia lies in Irkutsk Oblast (is quite common along the Birusa River valley but is very rare east of the valley - in the basins of rivers Angara, Iya, Oka, Nizhnyaya Tunguska) and Zabaykalsky Krai (vicinity of Nerchinsk) (Timokhina 1988, Chepinoga et al. 2008, MW, NSK). Initially recorded for Irkutsk Oblast in 1908 (Appendix 3), rather than in 1989 (Chepinoga et al. 2008). Probably an invasion species, rare in Eastern Siberia.

The species is common in the Central Asia, it is found in the North and the Center of Kazakhstan (mainly throughout river valleys), less common in the west and southwest. In the North Kazakhstan H. morsus-ranae often forms dense stands in watershed and valley lakes (Dobrokhotova 1956, Sviridenko 2000, LE, TK, MWG, AD). The southern border of its distribution reaches the Cisbalkhash, at ca. $43^{\circ} \mathrm{N}$. Records for Uzbekistan (Appendix 1: Invasive 2019, IUCN 2019) require clarification.

In Western Asia H. morsus-ranae is a rare species. In Turkey it is known from a few seaside regions: Strandja, Catal-
ca-Kocaeli, Western Black Sea, Middle Black Sea, Antalya (Appendix 1: Ekim 2012, E, W, Z+ZT). In Israel it is reported from Upper Galilee (Danin 2016), but is probably extinct in the wild (Sapir 2003). It is not known for Palestine (Ali-Shtayeh \& Jamous 2018). The species was reported for north and northwest Iran (Cook \& Lüönd 1982, Yousefi \& Toranj 2015, W), Iraq (Appendix: Iraqi 2010) and Syria (Flora Syria 2019). It is a neophyte, which was first reported for the region in 1977 (Assadi \& Wendelbo 1977).

Recently a few invasion sites were discovered in the Indian subcontinent (Jammu and Kashmir Himalaya). Hydrocharis morsus-ranae and $H$. dubia grow sympatrically in Miragund and Haigam wetlands (Ganie et al. 2016).

The species' status in North Africa (Algeria, Morocco, presumably Tunisia) (García et al. 2012, Appendix 1: IUCN 2019, Conservatoire 2019) is not clear, probably it is a neophyte. It is protected in the macroregion (García et al. 2010). In the South the species' distribution is supposedly limited by the Atlas Mountains, ca. $31^{\circ} \mathrm{N}$.

Hydrocharis morsus-ranae was first brought to North America in 1932 at the Ottawa botanic garden from Zurich and later noticed as an escapee in 1939 in the Rideau Canal (Dore 1968). This species then spread into the Ottawa and the St. Lawrence Rivers in 1974. By the early 1990s it had spread to the marshes and bays of Lake Ontario's south shore. In the USA, it is present in Michigan, Wisconsin, Vermont, New York, Washington and Florida states (Catling \& Dore 2003, Zhu et al. 2018, Appendix 1: INaturalist 2019, GBIF 2019). Recently, it was found further south and has been observed in Maine, Ohio and Pennsylvania states (Jacono \& Berent 2019). In Canada H. morsus-ranae is currently found in the southeastern part of the country (Ontario and Quebec) (Catling \& Dore 2003, Zhu et al. 2018). The species has become a source of concern due to its high invasion success (Zhu et al. 2018).

\section{Distribution of Hydrocharis dubia}

Hydrocharis dubia has a disjunctive Southeast Asian Australian subboreal-tropical range. The northern border reaches $46.5^{\circ} \mathrm{N}$, while the southern border $-35.2^{\circ} \mathrm{S}$, most of the known locations are situated $39-40^{\circ} \mathrm{N}$ and $7-10^{\circ} \mathrm{S}$. The western border goes along the Indo-Gangetic Plain, $35.3^{\circ} \mathrm{N}$.

Hydrocharis dubia is widely distributed in South-Eastern Asia, but is sporadically dispersed. In Indochina there are known localities in Bangladesh (Jessore, Manda Rajshahi (W, LE)), Thailand (Bangkok, Chaing Mai, Nakhon Ratchasima, Nakhon Sawan (QBG), Ang Thong, Saraburi, Sukhothai $(\mathrm{Z}+\mathrm{ZT})$, Rayong (probably in culture, QBG)). There are a few occurrences in Myanmar (Shan; distribution in other states requires clarification), Vietnam (mainly the southern part of the country - Long An Province, Dong Thap Province etc., Hanoi) and Laos (distribution pattern requires clarification) (Cook \& Lüönd 1982, Haynes 2001, Kress at al. 2003, Newman 2007, Ito \& Barfod 2014, Appendix 1: IUCN 2019, GBIF 2019). There is no reliable data on occurencies in Cambodia.

In the Malay Archipelago it is scattered and somewhat sparingly represented and apparently absent from several larger land masses (Malayan Peninsula, Sumatra and the Is- 
land of Borneo). There are known locations in Indonesia (Northen Java, Eastern ana Southern New Guinea, South and South-East Sulawesi, Philippines (Luzon)) and Oceania (Papua New Guinea (main island group)) (Den Hartog 1957, Ito \& Barfod 2014, Appendix 1: IUCN 2019, Pelser 2017, GBIF 2019, WAG, Z+ZT). The distribution pattern in the Republic of Singapore is not defined.

In the Indian subcontinent $H$. dubia occurs only in the north-west along the Himalayas Jammu and Kashmir, north-east Uttar Pradesh, north Bihar, West Bengal, probably Chhattisgarh) (Cook 1998, Guha \& Maondal 2005, Appendix 1: Barooah \& Iftikher 2014, GBIF 2019, WAG, W, $\mathrm{Z}+\mathrm{ZT}$ ). In Pakistan it is reported from the north-east, but the distribution pattern requires clarification (Appendix 1: Ghafoor 2019). It is quite a rare species in the macroregion, the number of habitats is reducing.

Hydrocharis dubia is common in China, Korea and Japan. It is found in the southern and eastern provinces of China (Anhui, Fujian, Guangdong, Guangxi, Northeast Hainan, Hebei, Heilongjiang, Henan, Hubei, Hunan, Jiangsu, Jiangxi, Jilin, Liaoning, Shaanxi, Shandong, Sichuan, Yunnan, Zhejiang), Hong Kong, Taiwan. It is also ubiquitous in Japan (Honshu, Shikoku, Kyushu, Okinawa, Ryukyu Islands) and Korean Peninsula (Cook \& Lüönd 1982, Wu 1986, Choi 2000, Chen et al. 2012b, Wang et al. 2010, Appendix 1: Chang et al. 2014, Japanese 2019, Global 2019, GBIF 2019, IBSC, LE, W, Z+ZT, SNU).

In the Russian Far East the species is found at the northern border of its range. The distribution is limited by the south of Primorsky Territory; it sporadically grows near Lake Khanka (LE, VLA). It was successfully introduced from Primorsk Power Station to the city of Khabarovsk and its vicinity in 2009-2013 (AD).

Hydrocharis dubia has a secondary enclave which includes the southern shore of Australia (Queensland and the northeastern part of New South Wales) (Cook \& Lüönd 1982, Appendix 1: IUCN 2019) and, possibly, some islands of Oceania. The species was first recorded for Australia by Bentham in 1873 under the misapplied name H. morsus-ranae. The record was based on a specimen collected by J. Bidwill, from "Wide Bay" between 1848 and 1853. There is a strong evidence to support an alien status for $H$. dubia with regard to its occurrences in Australia; it was recorded as naturalized for Australia (Bean 2011, Jacobs \& McColl 2011). Currently in Australia its distribution area stretches along the Great Dividing Range with most occurrences in the coastal area and a few specimens found west of the mountain range. The southern border of the distribution area is at $35.2^{\circ} \mathrm{S}$. The eastern border reaches North Stradbroke Island $\left(27.5^{\circ} \mathrm{S} 153.5^{\circ} \mathrm{E}\right)$.

\section{Distribution of Hydrocharis chevalieri}

Hydrocharis chevalieri range is continuous Central African (Guineo-Congolean) equatorial, extending northwards to $11.9^{\circ} \mathrm{N} 14.8^{\circ} \mathrm{E}$ and southwards to $5.0^{\circ} \mathrm{S} 18.8^{\circ} \mathrm{E}$. From the west coastal region of the Cameroons $\left(7.4^{\circ} \mathrm{N} 2.6^{\circ} \mathrm{E}\right)$ it extends eastwards to the Great Rift Valley $\left(3.7^{\circ} \mathrm{N} 29.8^{\circ} \mathrm{E}\right)$. Most of the known habitats are located in the Congo River basin. The area of distribution is widely separated from that of the other species of Hydrocharis.
Hydrocharis chevalieri is known from Cameroons (mainly southwestern regions) (BR, K, WAG, YA, Z+ZT), Gabon (Ngounié, l'Ogooué-Ivindo, l'Ogooué-Lolo, Woleu-Ntem) (WAG), Equatorial Guinea, Central African Republic (BR), Democratic Republic of the Congo (sporadically occurs in western and central regions but is rare in the east), Republic of the Congo $(\mathrm{Z}+\mathrm{ZT})$, there are also a few occurrences in Benin (West Africa) and in the north of Cameroons (Cook \& Lüönd 1982, Symoens 1984, Akoegninou et al. 2006, Symoens 2015, Sosef 2017, Appendix A: Conservatoire 2019, GBIF 2019). The species is not found in Eastern Africa - Rwanda and Burundi (Symoens 2015).

This Central African endemic is widespread in the region, but is found rarely enough (Lubina 1983). This species sporadically occurs in lowland rainforest region, but some occurrences are known in savanna region. Mainly it grows in small sedge swamps of rivers and streams. Often $H$. chevalieri dominates communities of wetland aquatic plants

\section{Paleohistory of the genus Hydrocharis}

The stem node age of Hydrocharis-Limnobium was dated around $54.7 \mathrm{Ma}$, the crown node age of this subclade was dated around 15.9 Ma. From there Limnobium had split from the relatively ancient Hydrocharis in the Miocene (Chen et al. 2012a). At least 10 members of the genus Hydrocharis are known (Kats et al. 1965, Krasilov 1976, Mai 1988, Carrión \& Dupré-Olivier 1996, Velichkevich \& Zastawniak 2003, Yao et al. 2011, Appendix 1: The International 2019, LEPAL) (Table 1), most of which existed in Oligocene and Miocene.

During the Eocene-Holocene H. morsus-ranae had a European-Siberian boreal distribution, with its Northern border located in the mouth of the river $\mathrm{Ob}, 66^{\circ} \mathrm{N}$. The fossil seeds of $H$. morsus-ranae occur in interglacial floras of different ages, but are never numerous in Europe, although relatively numerous in Western Siberia. Seeds of the same morphological type were described by Mai (2000) from the Late Miocene of Lusatia, the Pliocene of Thuringia and the Late Pliocene flora of Kholmech in southeastern Belarus (Mai 1988, Mai 2000, Velichkevich \& Zastawniak 2003). Seeds similar in description to $H$. dubia are known from the Tsagayan flora (Amur region, Russia), they are dated to the Late Cenonian - Paleocene (Krasilov 1976). No information on the paleontological findings of $H$. chevalieri, as well as other species of the genus, in Africa, was found.

\section{DISCUSSION}

Based on the calculation results we determined that plurizonal Eurasian - North American temperate H. morsusranae has the biggest area of the extent of occurrence, and the smallest area is that of equatorial $H$. chevalieri. Since the distribution pattern of water plants is mostly defined by the presence of suitable waterbodies, the area of occupancy is significantly smaller (Table 2).

Hydrocharis morsus-ranae is a widespread species with numerous and quite stable populations, with irregular sexual reproduction and prevalent vegetative reproduction, so its global threat status is given as LC (IUCN 2019, Table 3). However, in some parts of the range (Central (some regions), Western (some regions) and Southern Europe, Caucasia, 
Table 1. Paleontological findings of species of the genus Hydrocharis

\begin{tabular}{|c|c|c|c|}
\hline Species & Fossil status & Stratigraphy & Location \\
\hline Hydrocharis batrachodigma A. Massal. & leaves & Oligocene & Schiavon (Chiavon), Vicenza, Veneto, Italy \\
\hline Hydrocharis langsdorfii R. Ludw. & leaves & Miocene & Salzhausen, near Nidda, Wetterau, Hessen, Germany \\
\hline Hydrocharis lusatica Mai in Mai, H. Walther & seeds & Miocene & Oberoderwitz borehole, Saxony, Germany \\
\hline Hydrocharis magna Mai in Mai, H. Walther & seeds & Oligocene & Haselbach, Landkreis Altenburg, Thuringia, Germany \\
\hline Hydrocharis morsus-ranae $\mathrm{L}$. & seeds, pollen & $\begin{array}{l}\text { Eocene - } \\
\text { Holocene }\end{array}$ & $\begin{array}{l}\text { Navarrés, eastern Spain; Poland; Belarus; Lithuania; Ukraine; } \\
\text { Voronezh region, Lower Kama, Upper Volga, Western Sibe- } \\
\text { ria (common in the south, the northern border is the mouth } \\
\text { of the Ob, Russia) }\end{array}$ \\
\hline Hydrocharis orbiculata Heer & leaves & $\begin{array}{l}\text { Miocene } \\
\text { ('Tortonian) }\end{array}$ & $\begin{array}{l}\text { Öhningen, Landkreis Konstanz, Baden-Württemberg, Ger- } \\
\text { many }\end{array}$ \\
\hline Hydrocharis ovata R. Ludw. & $\begin{array}{l}\text { leaves and } \\
\text { flowers }\end{array}$ & Miocene & Salzhausen, Münzenberg, Wetterau, Hessen, Germany \\
\hline Hydrocharis rottensis Weyl. & not available & $\begin{array}{l}\text { Oligocene } \\
\text { (Chattian, Rott } \\
\text { Formation) }\end{array}$ & Rott near Bonn, North Rhine-Westphalia, Germany \\
\hline Hydrocharis tertiaria Hartz & seeds & Miocene & Sønderskov near Silkeborg, Jutland, Denmark \\
\hline Hydrocharis of. dubia (Blume) Backer & leaves & $\begin{array}{l}\text { Late Senon - } \\
\text { Paleocene }\end{array}$ & Amur region, South of Russia Far East \\
\hline Hydrocharis sp. & not available & Miocene & South China \\
\hline Hydrocharis sp. & seeds & $\begin{array}{l}\text { Oligocene, } \\
\text { Miocene, } \\
\text { Neopleistocene }\end{array}$ & South of Western Siberia \\
\hline Hydrocharis sp. & pollen & $\begin{array}{l}\text { Upper Pliocene - } \\
\text { Middle Pleistocene }\end{array}$ & Caspian Lowland (Baku) \\
\hline
\end{tabular}

Table 2. Main characteristics of the range of the species of Hydrocharis

\begin{tabular}{|c|c|c|c|}
\hline Characteristic & Hydrocharis chevalieri & Hydrocharis dubia & Hydrocharis morsus-ranae \\
\hline Extent of occurrence, $\mathrm{Mkm}^{2}$ & 3.134 & 6.820 & 16.030 \\
\hline Area of occupancy, $\mathrm{Mkm}^{2}$ & 0.074 & 0.199 & 0.785 \\
\hline Extreme latitudes & $11.9^{\circ} \mathrm{N}-5.0^{\circ} \mathrm{S}$ & $46.5^{\circ} \mathrm{N}-35.2^{\circ} \mathrm{S}$ & $68.9^{\circ} \mathrm{N}-33.1^{\circ} \mathrm{N}$ \\
\hline Extreme longitudes & $2.6^{\circ} \mathrm{E}-29.8^{\circ} \mathrm{E}$ & $72.6^{\circ} \mathrm{E}-153.0^{\circ} \mathrm{E}$ & $90^{\circ} \mathrm{W}-122.0^{\circ} \mathrm{E}$ \\
\hline
\end{tabular}

Table 3. Assessment of the conservation status of the species of Hydrocharis. Note: CR - critically endangered; EN endangered; EW - extinct in the wild, VU - vulnerable; NT - near threatened; LC - least concern

\begin{tabular}{|c|c|c|}
\hline Species & $\begin{array}{l}\text { Category for the } \\
\text { World }\end{array}$ & Category for macroregions \\
\hline Hydrocharis chevalieri & LC & BENIN AND CAMEROON (savana regions): probably NT (A4c,B) (AD) \\
\hline Hydrocharis dubia & $\mathrm{LC}$ & $\begin{array}{l}\text { SOUTH-EAST AsIa: probably NT (AD); JAPAN: NT (Appendix 1: Global 2020); } \\
\text { INDIAN SUBCONTINENT: probably NT/NU (AD); RUSSIAN FAR EAST: NT (AD) }\end{array}$ \\
\hline Hydrocharis morsus-ranae & $\mathrm{LC}$ & $\begin{array}{l}\text { WESTERN EUROPE: United Kingdom and Ireland - VU (A2c) (Cheffings \& Farrell } \\
\text { 2005), South France - EN/CR (Appendix 1: Inventaire 2019), Belgia - VU/CR (Bel- } \\
\text { gian 2019); CENTRAL EuropE: Czech Republic and Slovakia - EN (C2b) (Danihelka et } \\
\text { al. 2012, Kaplan 2018), Germany, Austria, Slovenia - EN/CR (Schill \& Krautkrämer } \\
\text { 2019, AD); Switzerland - EN (B2ab(iii,iv) (Appendix 1: Info flora 2019); Slovenia } \\
\text { - EN (AD) ;Southern Europe: Italy - NT, Portugal and Spain - CR , other country } \\
\text { - EN/CR (Beck von Mannagetta 1904, Talavera 2010, Dÿigurski et al. 2010, Dimo- } \\
\text { poulos 2013, Nikolić 2015, Barina 2017); Caucasus: Georgia, Azerbaijan - probably } \\
\text { EW (AD); MidDLE AND EASTERN SIBERIA: NT - (Chepinoga et al. 2008; AD); prob- } \\
\text { ably neophyte in Eastern Siberia; WESTERN AsIA: Iran, Iraq - probably neophyte (As- } \\
\text { sadi \& Wendelbo 1977), Israel - EW (Sapir 2003); NoRTH AFRICA: EN (García et al. } \\
\text { 2010), probably neophyte. }\end{array}$ \\
\hline
\end{tabular}

Western Asia) the number of populations and their area is reduced due to degradation of the typical habitats (Table 3). It is probably extinct in the wild in Azerbaijan (since late XX) and Israel (since 2000s). In the Asian part of the range (most of the regions of Russia and Kazakhstan) the population status does not cause concern. In regions with intensive agricultural activity (e.g. Ciscaucasia, some regions of Kazakhstan) population numbers are somewhat reduced, however, in such areas $H$. morsus-ranae often populates technogenic waterbodies.
Hydrocharis dubia is widespread only in subtropical and tropical regions, its global threat status is given as LC (IUCN 2019). In some territories, there is a destruction of habitats due to agricultural and industrial activities (South-Eastern Asia, Indian subcontinent); at northern borders the populations are quite small as well (Russian Far East) (Table 3). The global threat status of $H$. chevalieri according to IUCN is given as LC (IUCN 2019), in savana regions status probably is NT. Although this species is scattered in its distribution area, due to the big extent of occurrence and common 
habitats we consider that the IUCN assessment is appropriate. Probably $H$. chevalieri is simply undercollected. Probable causes of the decline and extinction of Hydrocharis populations include degradation of habitats (agricultural and industrial activities), and changes of hydrochemical characteristics and the hydrological regime of waterbodies. Hydrocharis morsus-ranae and $H$. dubia respond well to moderate eutrophication, thought excessive concentrations of some components can detrimentally affect the plants. Poor seed reproduction and sexual segregation are limiting the possibilities of seed regeneration.

There are some abiotic factors limiting the spreading along with the geographical ranges of Hydrocharis species. The mean annual temperature is the most contrasting feature of the distribution areas of the species (Table 4, q.v. material and methods, indicators BIO3, BIO2). Such features of the habitats as water depth, bottom soil type and hydrochemical composition are also significant factors. Comparative analysis of the tolerance boundaries of Hydrocharis species in the global range is given in the Table 4. The spread along the northern boundary is limited not only by mean annual temperatures, but also by ultra-fresh water and oligotrophic water bodies, that are unsuitable for $H$. morsus-ranae. Hydrocharis dubia and $H$. chevalieri are more thermophilic, and their suitable biotops (shallow mesotrophic waterbodies with very weak or absent current and muddy bottom sediments) are transformed or destroyed during agriculture and mining activities.

Hydrocharis morsus-ranae and $H$. dubia are used as ornamental, fodder, fishery and water protection plant; H. morsus-ranae and H. chevalieri also as medicinal plant (Den Hartog 1957, Dubina et al. 1993, Sosef 2017). Hydrocharis chevalieri is used for the production of salt from ash (Sosef 2017), in Gabon leaves are used for preparing tea (Mesterházy ined.). In the 20th century water transport and ornamental gardening also became a significant factor of invasion. It is possible that waterfowl migration could transport viable vegetative diaspores across water basins at relatively short distances. In such a way recently $H$. morsus-ranae broke down of the historical biogeographic barrier, invasion sites were discovered in Kashmir Himalaya, on the border of $H$. dubia range (Ganie 2016). The performed modeling (Fig. 2) allows assessing the possible potential of invasion of the studied species.

Despite quite abundant flowering and fruiting of $H$. morsus-ranae and $H$. dubia (apart from northern borders), vegetative reproduction plays a great part in maintaining population sizes. Specialized turions (hibernacula) allow H. morsus-ranae and $H$. dubia to tolerate a brief period of freezing conditions (Catling et al. 2003), which helps expanding northern distribution borders. In some regions, the ability of $H$. morsusranae (e.g. the US, Canada) and H. dubia (e.g. Australia) to spread rapidly by vegetative organs causes significant economic and environmental damage. Dense clones limit the growth of other aquatic species, change hydrochemical composition of the water, affect the development of phytoplankton, and can interfere with navigation and irrigation systems.

\section{CONCLUSIONS}

The modern Hydrocharis morsus-ranae range is disjunctive Eurasian - North American temperate, limited by annual isotherms at $9.9^{\circ} \mathrm{C}$. The species expanded its secondary range significantly, primarily in North America since 1930-1940s. New invasion localities also have appeared in some regions of the Western Asia, the Middle and the Eastern Siberia, the Indian subcontinent and probably in the North Africa due to high economic activities since 1970-1980s. Currently, there is an expansion of the nor-

Table 4. Limits of ecological tolerance of Hydrocharis species according to some indicators

\begin{tabular}{|c|c|c|c|}
\hline \multirow{2}{*}{ Environmental factors } & \multicolumn{3}{|c|}{ The range of variation of the factor (optimum) within global habitat } \\
\hline & Hydrocharis chevalieri & Hydrocharis dubia & Hydrocharis morsus-ranae \\
\hline $\begin{array}{l}\text { Annual precipitation, mm } \\
\text { (Appendix 1: WorldClim2019) }\end{array}$ & $1400-2600(\approx 1800-2400)$ & $800-3200(\approx 1200-2000)$ & $400-2000(\approx 600-1000)$ \\
\hline $\begin{array}{l}\text { Mean annual temperature, }{ }^{\circ} \mathrm{C} \\
\text { (Appendix 1: WorldClim2019) }\end{array}$ & $20.1-25.0(\approx 20.1-25.0)$ & $1.0-30.0(\approx 10.1-25.0)$ & $-9.9-20.0((\approx 1.0-15.0)$ \\
\hline $\begin{array}{l}\text { Altitude, m above see level (Cook } \\
\text { \& Lüönd 1982, Appendix 1: } \\
\text { WorldClim 2019) }\end{array}$ & $\begin{array}{l}0-1000(\approx 100-500) \\
\text { (WAG, YA) }\end{array}$ & $\begin{array}{l}0-2600(\approx 0-1000) \\
\text { (Den Hartog } 1957, \text { Haynes } \\
\text { 2001, IBSC, LE, Z+ZT, W) }\end{array}$ & $\begin{array}{l}0-1600(\approx 0-500) \\
(\mathrm{BP}, \mathrm{E})\end{array}$ \\
\hline $\begin{array}{l}\text { Type of water body (Cook \& } \\
\text { Lüönd 1982) }\end{array}$ & $\begin{array}{l}\text { Flooded swamps, aquatic } \\
\text { meadows, streams in forest (still } \\
\text { waters), bare mud, thalweg with } \\
\text { periodical floods, small swampy } \\
\text { hollows, small waterbodies } \\
\text { (Lubini 1983) }\end{array}$ & $\begin{array}{l}\text { Shallow water bodies or slow } \\
\text { moving streams, marshes, locally } \\
\text { swamp forest, ditches, ponds, } \\
\text { reservoirs, habitats that dry out } \\
\text { each year (Den Hartog } 1957 \text {; } \\
\text { AD) }\end{array}$ & $\begin{array}{l}\text { Small waterbodies, sheltered } \\
\text { bays or inlets of larger lakes } \\
\text { and rivers; oxbow lakes, canals, } \\
\text { ditches, reservoirs, flooded } \\
\text { swamps, habitats that dry out } \\
\text { each year (Dubina et al. } 1993 \text {, } \\
\text { Sviridenko 2000, AD) }\end{array}$ \\
\hline Depth, m & $0.0-0.6(\approx 0.3)($ Lubini 1983) & $0.1-3.0(\approx 0.5-1.5)(\mathrm{AD})$ & $\begin{array}{l}0.1-2.0(\approx 0.5-1.5)(\text { Cook } \& \\
\text { Lüönd } 1982, \text { Sviridenko } 2000 \text {, } \\
\text { Dubina et al. } 1993, \text { AD) }\end{array}$ \\
\hline Type of bottom deposit & Silty, silty-detrital (Lubini 1983) & $\begin{array}{l}\text { Silty, silty-peaty, wet mud (Cook } \\
\text { \& Lüönd 1982, AD) }\end{array}$ & $\begin{array}{l}\text { Silty, silty-peaty, sandy (Cook \& } \\
\text { Lüönd 1982, Sviridenko } 2000 \text {, } \\
\text { AD) }\end{array}$ \\
\hline $\mathrm{pH}, \mathrm{pH}$ units & 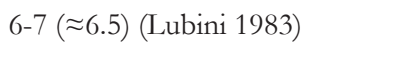 & $\approx 7.0(\mathrm{AD})$ & $\begin{array}{l}\text { 6.4-8.8 }(\approx 7.0) \text { (Sviridenko 2000, } \\
\text { AD) }\end{array}$ \\
\hline Trophicity & $\approx$ mesoeutrophic $(\mathrm{AD})$ & $\begin{array}{l}\text { mesoeutrophic - eutrophic } \\
(\approx \text { mesoeutrophic }) \\
(\text { AD })\end{array}$ & 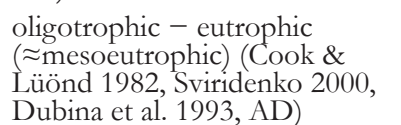 \\
\hline
\end{tabular}



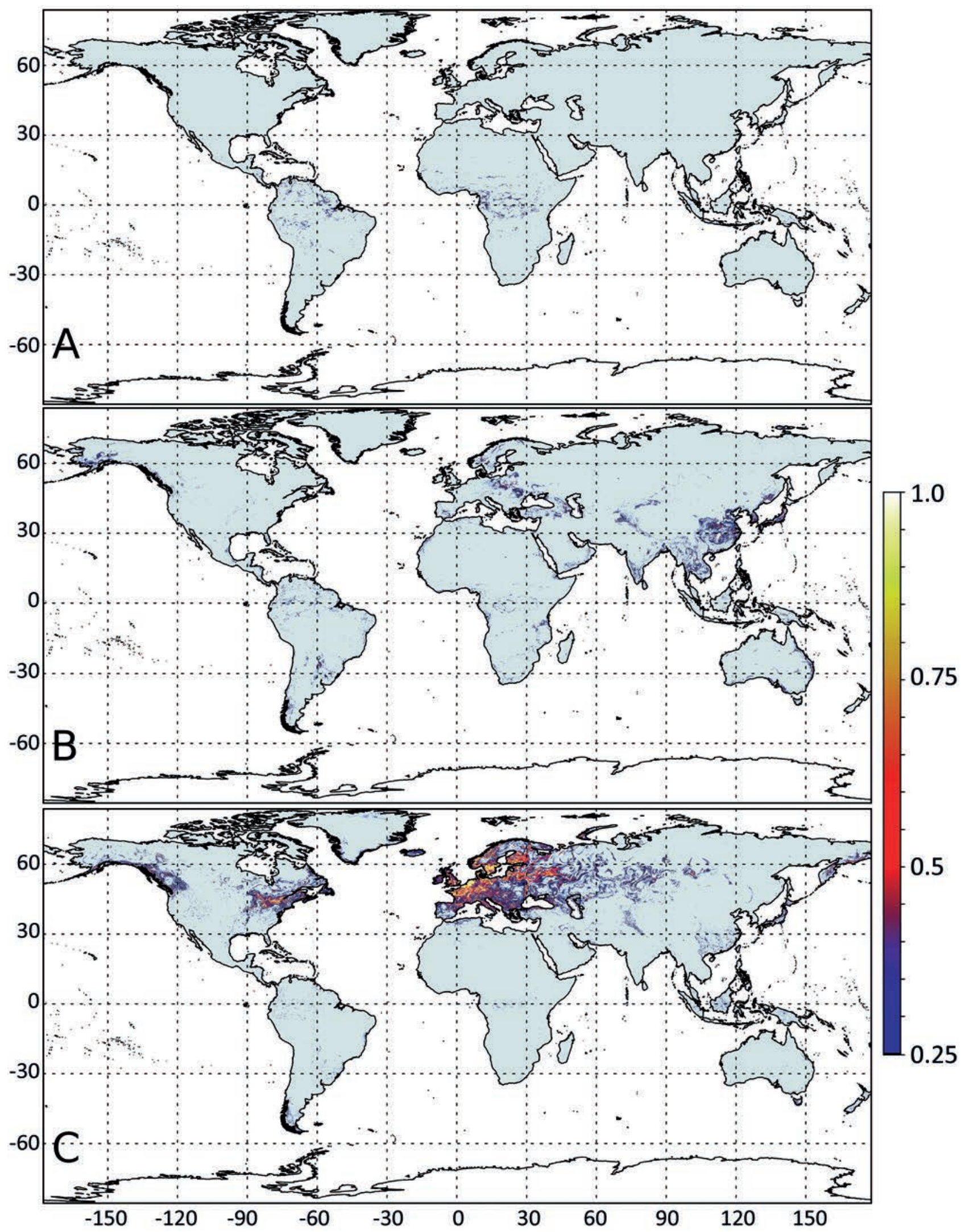

Figure 2 The model showing the potential distribution range of Hydrocharis chevalieri (De Wild.) Dandy (A); H. dubia (Blume) Backer (B) and H. morsus-ranae L. (C)

thern and eastern distribution borders. Meanwhile in the Western and the Southern Europe, the Western Asia area occupied by populations is reduced. On the other hand anthropogenic activities (the building of reservoirs, agriculture, etc.) and increasing eutrophication contribute to the distribution in secondary habitats (e.g. Central Europe, Caucasia). Hydrocharis dubia has a disjunctive Southeast Asian - Australian subboreal-tropical range. Extensive enclave in Aust- 
ralia probably formed in 1850-1870s. Distribution of this thermophilic species is limited by mean annual temperature $1.0-30.0^{\circ} \mathrm{C}$. In the South-Eastern Asia, Japan, the Indian subcontinent there is a decrease in the number of known habitats and population sizes of H. dubia. Hydrocharis chevalieri is a macrothermal Central African (Guineo-Congolean) equatorial species. The current world threat status of all species of genus Hydrocharis may be estimated as LC.

\section{ACKNOWLEDGEMENTS}

We would like to thank the staff of the herbarium and paleontological collection (q.v. Appendix 2) for the help and permission to work, Dr Zoltán Barina (Hungarian Natural History Museum, Budapest), Dr Thomas Abeli (Roma Tre University, Rome) for rare literary sources, the review and suggestions to improve the manuscript. We are grateful to A.V. Ermoshkin for the help with clarification of the distribution of the species in the Khabarovsk Krai, J.-P. Ghogue (Green Connexion, Yaounde) for his help with herbarium materials of $H$. chevalieri, Eugenio MolinaNavarro (University of Copenhagen, Copenhagen) for provided geospatial data.

\section{LITERATURE CITED}

Akoegninou, A., W.J. van der Burg \& L.J.G. van der Maesen 2006. Flore analytique du Benin. Backhuys Publishers, Kerkwerve, $1034 \mathrm{pp}$.

Amante, C. \& B. Eakins 2009. ETOPO1 1 Arc-Minute Global Relief Model: Procedures, Data Sources and Analysis. NOAA Technical Memorandum NESDIS NGDC-24. Colorado, 26 pp. DOI: $10.7289 /$ V5C8276M.

Ali-Shtayeh, M.S. \& R.M. Jamous 2018. Updating the plant 'Red List' of Palestine (West Bank and Gaza Strip): conservation assessments and recommendations. Journal of Biodiversity \& Endangered Species 6:3.

Antipova, E.M. 2012. Flora of the inland island forest-steppe of Central Siberia. Krasnoyarsk, 662 pp. (in Russian). [Антипова Е.M. 2012. ФАора внутриконтинентальных островных месостепей Средней Сибири. Красноярск. 662 с.].

Assadi, M. \& P. Wendelbo 1977. New and interesting plant records from NW Iran. Iranian Jouranal of Botany 1:97-108.

Barina, Z. 2017. Distribution atlas of vascularplants in Albania. Budapest, 492 pp.

Bean, A.R. 2011. Hydrocharis dubia (Blume) Backer (Hydrocharitaceae) is an alien species in Australia. Austrobaileya $8: 435-437$.

Beck von Mannagetta, G. 1904. Beitrag zur Flora des östlichen Albanian. Annales Naturbistorisches Hofmuseum 19: 69-78.

Birkmane, K. 1953. Mazlēpju dzimta - Hydrocharitaceae. In: Latvijas PSR Flora, vol. 1 (P. Galenieks, ed.), pp. 127130, Latvijas Valsts Izdevnieciba, Riga.

Bulohov, A.D. \& E.M. Velichkin 1998. Manual of plants of southwestern Nonblack. Soil Zone of Russia (Bryansk, Kaluga, Smolensk Regions). Bryansk, 380 pp. (in Russian). [Булохов А.А., Величкин Э.М. 1998. Определитель растений Юго-Западного Нечерноземья России (Брянская, Калужская, Смоленская об̆ласти). Брянск. 380 с.].

Carrión, J.S. \& M. Dupré 1996. Late Quaternary vegetational history at Navarrés, Eastern Spain. A two-core approach. New Phytologist 134:177-191.
Catling, P.M., G. Mitrow, E. Haber, U. Posluszny \& W.A. Charlton 2003. The biology of Canadian weeds. 124. Hydrocharis morsus-ranae L. Canadian Journal of Plant Science 83:1001-1016.

Chepinoga, V.V., N.V. Stepantsova, A.V. Grebenjuk, A.V. Verkhozina, O.P. Vinkovskaya, A.A. Gnutikov, N.A. Dulepova, I.V. Enushchenko, A.M. Zarubin, S.G. Kazanovsky, A.S. Konovalov, A.A. Korobkov, A.N. Luferov \& S.A. Rosbakh 2008. Checklist of the flora of Irkeutsk Region (vascular plants), Irkutsk, 327 pp. (in Russian) [Чепинога В.В., Степанцова Н.В., Гребенюк А.В., Верхозина А.В., Виньковская О.П., Гнутиков А.А., Аулепова Н.А., Енущенко И.В., Зарубин А.М., Казановский С.Г., Коновалов А.С., Коробков А.А., Ауферов А.Н., Росбах С.А. 2008. Конспект фморы Иркутской области (сосудистые растения). Иркутск, 327 с.].

Chen, L.-Y., J.-M. Chen, R. Gituru \& Q.-F. Wang 2012. Generic phylogeny, historical biogeography and character evolution of the cosmopolitan aquatic plant family Hydrocharitaceae. BMC Evolutionary Biology 12:30.

Chen, Y.D., X.T. Ma, Y.F. Du, M. Feng \& M. Li 2012. The Chinese aquatic plants. Zhengzhou, 479 pp.

Cheffings, Ch.M. \& L. Farrell (eds.). 2005. The vascular plant Red Data List for Great Britain. Species status No. 7. Peterborough, $120 \mathrm{pp}$.

Choi, H.K. 2000. Aquatic vascular plants. In: Plants of Korea, vol. 5, pp. 190-191. Korea Research Institute of Bioscience and Biotechnology, Junghengsa, Seoul (in Korean).

Conti, F., Abbate, G., Alessandrini, A. \& Blasi, C. (eds.) 2005. An annotated checklist of the Italian vascular flora. Palombi Editori, Roma, 428 pp.

Cook, C.D.K. 1996. Aquatic and wetland plants of India. New York, 385 pp.

Cook, C.D.K. \& R. Lüönd 1982. A revision of the genus Hydrocharis (Hydrocharitaceae). Aquatic Botany 14: 177-204.

Danihelka, J., J. Chrtek \& Z. Kaplan 2012. Checklist of vascular plants of the Czech Republic. Preslia 84:647-811.

Den Hartog, C. 1957. Hydrocharitaceae. In: Flora Malesiana, vol. 5 (C.G.G.J. Van Steenis, ed.), p. 381-413, NoordhoffKolff, Groningen.

Dimopoulos, P., T. Raus, E. Bergmeier, T. Constantinidis, G. Iatrou, S. Kokkini, A. Strid \& D. Tzanoudakis 2013. Vascular plants of Greece: an annotated checklist. Englera $31: 1-372$.

Dobrochaeva, D.N., M.I. Kotov \& Y.N. Prokudin 1987. Field guide to higherplants of Ukraine. Naukova dumka, Kiev, 548 pp. (in Russian). [Аоброчаева А.Н., Котов М.И., Прокудин Ю.Н. 1987. Полевой определитель высших растений Украины. Киев: Наукова думка. 548 с.].

Dobrokhotova, K.V. 1956. Hydrocharitaceae - Frogbit Family. In: Flora of Kazakhstan, vol. 1 (N.V. Pavlov, ed.), pp. 110-112, Izdatel'stvo akademii nauk Kazakhskoi SSR, Alma-Ata (in Russian). [Аоброхотова, K.В. 1956. Hydrocharitaceae - Водокрасовые // Фмора Казахстана / под ред. Н.В. Павлова. Алма-Ата: ИзА-во Академии наук КазССР. Т.1. С. 110-112].

Dore, W.G. 1968. Progress of the European frog-bit in Canada. The Canadian field-naturalist 82:76-84.

Dubina, D., S. Geini \& Z. Groudova 1993. Macrophytes indicators of environmental changes. Naukova Dumka, Kyiv, 463 pp. (in Russian). [Аубына А., Гейны С., Гроудова 3. 1993. Макрофиты - индикаторы изменений природной среды. Киев: Наукова Аумка. 463 с.]. 
Dubovik, D.V. 2013. Hydrocharitaceae Juss. - Frogbit family. In: Flora of Belarus. Vascular plants, vol. 2 (V.I. Parfenov, ed.), pp. 94-102, Belaruskaya Navuka, Minsk (in Russian). [Аубовик А.B. 2013. Hydrocharitaceae Juss. Водокрасовые / Флора Беларуси. Сосудистые растения. Минск: Беларуская навука. Т. 2. С. 94-102].

Dÿigurski, D.M., S.J. Stojanoviã, A.S. Kneÿeviã, L.M. Nikoliã \& B.B. Ljevnaiã-Mašiã. 2010. Vegetation of the classes Hydrochari-Lemnetea Oberd. 1967 and Potametea Tx. et Prsg. 1942 in the Jegriaaka watercourse (The Province of Vojvodina, Serbia). In: Proceedings for Natural Sciences, Matica Srpska Novi Sad 118:99-106.

Ebel, A.L. 2012. Cheklist of the flora of NW part of Altai-Sayan Province. Kemerovo, 568 pp. (in Russian) [Эбель А.А. 2012. Конспект флоры северо-западной части А^таеСаянской провинции. Кемерово, 568 с.].

Filippova, N.Yu. 1997. Palynology of the upper Pliocene - middle Pleistocene of the south of the Caspian region. Geos, Moscow, 164 pp. (in Russian). [Филиппова Н.Ю. 1997. Палинология верхнего плиоцена - среднего плейстоцена юга Каспийской области. М.: Геос. 164 с.].

Gagnidze, R. 2005. Vascular plants of Georgia: a nomenclatural checklist. Georgian Academy of Sciences, Tbilisi, 248 pp.

Ganie, A.H., A. Bashir, A.A. Khuroo, B.A. Tali, Z.A. Reshi, M.A. Shah \& B.A. Wafai 2016. A new record of an invasive aquatic plant Hydrocharis morsus-ranae (Hydrocharitaceae), reaching to the Kashmir Himalaya. Journal of Japanese Botany 91:100-104.

García, N., A. Cuttelod \& D.A. Malak 2010. The status and distribution of freshwater biodiversity in Northern Africa. World Conservation Union, Gland, 141 pp.

Geideman, T.S. 1986. Guide to higher plants of Moldavian SSR. Shtiintsa, Kishinev, 638 р. [Гейдеман T.C. 1986. Определитель высших растений Молдавский ССР. Кишинев: Штиинца, 638 с.].

Guha, R. \& M. Mondal 2005. Wetlandphytodiversity: a complete guide to Indian Helobieae. Scientific Publishers, Jodhpur, 274 pp.

Gusev, Yu.D. 1979. Hydrocharitaceae Juss. - Frogbit Family. In: Flora of the European Part of the USSR, vol. 4 (N.N. Tsvelyov, ed.), pp. 167-170, Nauka, Leningrad (in Russian). ГГусев Ю.А. 1979. Hydrocharitaceae Juss. Водокрасовые / / ФАора Европейской части СССР / отв. реА. Н.Н. Цвелев. А.: Наука, Т. 4. С. 167-170].

Hartvig, P., P. Vestergaard \& D.B. Forening. 2015. Atlas flora Danica, vol. 1-3. Gyldendal.

Haynes, R.R. 2001. Hydrocharitaceae. In: Flora of Thailand, vol. 7(3) (T. Santisuk \& K. Larsen, eds), pp. 365-382. The Forest Herbarium, Royal Forest Department, Bangkok.

Ito, Y. \& A. Barfod. 2014. An updated checklist of aquatic plants of Myanmar and Thailand. Biodiversity Data Journal 2:e1019.

Garielyan, E.Ts. \& A.G. Oganisyan (eds.). 2001. Flora of Armenia, vol. 10, Monocotyledones (excluding Poaceae). Gantner, Erevan, 547 pp. (in Russian) [Фцора Армении 2001 / отв. ред. Э.Ц. Гариэлян и А.Г. Оганесян. Ереван: Гантнер. T. 10. Monocotyledones (исключая Роасеаe). 547 с.].

IUCN 2012. Guidelines for Application of IUCN Red List Criteria at Regional and National Levels. Ver. 4.O. IUCN Species Survival Commission, IUCN, Gland, Switzerland and Cambridge, UK, 41 pp.

Ivanov, A.L. 2019. Checklist of the flora of Russian Caucasus (vascular plants). Stavropol, 341 pp. (in Russian). [Ива- нов А.А. 2019. Конспект флоры Российского Кавказа (сосудистые растения). Ставрополь. 341 с.].

Jacobs, S.W. \& K.A. McColl 2011. Hydrocharis. In: Flora of Australia, vol. 39, pp. 21-22, Australian Biological Resources Study/CSIRO Publishing, Melbourne.

Jankovich, M.M., M. Josifové \& N. Diklié 1975. Hydrocharitaceae. In: Flora Srbije, vol. 7 (M. Josifové \& M.R. Sarych, eds), pp. 476-477, Serbian Academy of Sciences Belgrade (in Serbian). Јанковић М., Јосифовић М., Аиклић Н. 1975. Hydrocharitaceae // ФАора СР Србије / ур. еА. М. Јосифовић, М.Р. Сарић. БеограА: Српске академије наука и уметности. Т. 7. С. 476-477].

Jordanov, D. 1963. Hydrocharitaceae. In: Flora of the Republic of Bulgaria, vol. 1 (D. Jordanov, ed.), pp. 223-231, Bulgarian Academy of Sciences, Sofia (in Bulgarian). Г̆орданов $A$. 1963. Hydrocharitaceae // Фцора на НР Бъмгария / поА ред. А. Йорданова. София: изА-во БАН. Т. 1. С. 223-231].

Kamyshev, N.S. 1978. Flora of the Central Black Soil Region and its analysis. Izd-vo VGU, Voronezh. 116 pp. (in Russian) [Камышев Н.С. 1978. ФАора Центрального Черноземья и ее анализ. Воронеж: ИзА-во ВГУ. 116 с.].

Kaplan, Z., J. Danihelka, J. Chrtek, J. Prančl, M. Ducháček, L. Ekrt, J. Kirschner J. Brabec, J. Zázvorka, B. Trávníček, P. Dřevojan, K. Šumberová, P. Kocián, J. Wild \& P. Petř́k 2018. Distributions of vascular plants in the Czech Republic. Part 7. Preslia 90:425-531.

Kats, N.Ya., S.V. Kats \& M.G. Kipiany 1965. Atlas and quide for fruits and seeds found in Quaternary deposits of the USSR. Nauka, Leningrad, 366 pp. (in Russian) [Кац Н.Я., Кац С.В., Кипиани М.Г. 1965. Атлас и определитель плОАОВ и семян, встречающихся в четвертичных отможениях СССР. $\Lambda .:$ Наука. 366 с.].

Király, G. \& R. Vidék. Hydrocharitaceae - Békatutajfélécsaládja. In: Új Magyar Füvészkönyv. Magyarország hajtásos növényei (G. Király, sz.), old. 468-470, Aggteleki Nemzeti Park Igazgatóság, Jósvafő.

Kochjarová, J., R. Hrivnák, H. Ot’ahel’ová, D. Dúbravková, P. Pal'ove-Balang, M. Novikmec, L. Hamerlík \& M. Svitok 2013. Aktuálne údaje o vỳskyte niektorỳch vodnỳch a močiarnych rastlín na Slovensku. Bulletin Slovenskej botanickej spoločnosti 35:107-118.

Krasilov, V.A. 1976. Tsagayansky Flora of Amur Region. Nauka, Moscow, 93 pp. (in Russian) [Красилов B.A. 1976. Цагаянская флора Амурской области. М.: Наука. 93 с.].

Kravchenko, A.V. 2007. Checklist of the Karelian flora. Petrozavodsk, 403 pp. (in Russian) [Кравченко A.B. 2007. Конспект флоры Карелии. Петрозаводск, 403 с.].

Kress, W.J., R.A. De Filipps, E. Farr \& D.Y.Y. Kyi 2003. A checklist of the trees, shrubs, herbs, and climbers of Myanmar. Contributions from the United States National Herbarium 45:1-590.

Kulikov, P.V. 2010. Manual of the vascularplants of Chelyabinsk Region. Ekaterinburg, 759 pp. (in Russian) [Куликов П.В. 2010. Определитель сосудистых растений Челябинской области. Екатеринбург. 759 с.].

Lellep, E. 1984. Kilbukalised - Hydrocharitaceae. In: EEsti NSV Flora, vol. 9, pp. 33-39.

Lubini, A. 1983. Association herbeuse aquatique à Hydrocharis chevalieri dans la région de Kisangani (Haut-Zaïre). Bulletin du Jardin botanique national de Belgique 53:331-342.

Maevsky, P. F. 2014. Flora of the midland of the European part of Russia. KMK, Moscow, 635 pp. (in Russian). [Маев- 
ский П.Ф. 2014. ФАора средней полосы европейской части России. М.: КМК. 635 с.].

Mai, D.H. 2000. The Lower Miocene floras of the Spremberger sequence and the second browncoal horizon in the Lusatica region Part IV: Collection sites and Palaeobiology. Palaeontographica Abteilung B 254:65-181.

Mai, D.H. \& H. Walther 1988. Die pliozänen Floren von Thüringen. Quartärpaläontologie 7:55-295.

Martinčič, A. \& F. Susnik 1969. Mala flora Slovenije. Ljubljana, $845 \mathrm{pp}$

Martynenko, V.A. \& B.I. Gruzdev 2008. Vascularplants of the Republic of Komi. Syktyvkar, 136 pp. (in Russian) [Мартыненко В.А., ГрузАев Б.И. 2008. Сосудистые растения Республики Коми. Сыктывкар. 136 с.].

Micevski, K. 1969. Die wasservegetation der seen von Ohrid und Prespa. Musei Macedonici Scientiarum Naturalium 11:61-80.

Minyaev, N.A., N. I. Orlova \& V.M. Schmidt 1981. The field guide of higher plants in the Northwest of the European part of the RSFSR (Leningrad, Pskov and Novgorod Regions). Izd-vo Leningradskogo Universiteta, Leningrad. 190 pp. [Минаев Н.А., Орлова Н.И. Шмилт В.М. 1981. Помевой определитель высших растений северо-запада европейской части РСФСР (Аенинградская, Псковская и Новгородская области). А.: ИзА-во Аенингр. ун-та. 190 с.].

Murphy K., A. Efremov, T.A. Davidson, E. Molina-Navarro, K. Fidanza, T.C.B. Crivelari, P. Chambers, J.G. Tapia, S.M. Varandas, I. Springuel, M. Kennedy, R.P. Mormul, E. Dibble, D. Hofstra, B.A. Lukács, D. Gebler, L. BaastrupSpohr \& J. Urrutia-Estrada 2019. World distribution, diversity and endemism of aquatic macrophytes. Aquatic Botany 158:103-127.

Newman, M., S. Ketphanh, B. Svengsuksa, P. Thomas, K. Sengdala, V. Lamxay \& K. Armstrong 2007. A checklist of the vascular plants of Lao PDR. Edinburgh, $401 \mathrm{pp}$.

Nikitin, V.P. 2007. Paleocarpology and stratigraphy of the Paleogene and Neogene of Asian part of Russia. Geo, Novosibirsk, 229 pp. (in Russian). [Никитин В.П. 2007. Палеокарпомогия и стратиграфия палеогена и неогена Азиатской России. Новосибирск: Гео. 229 с.].

Novosad, V.V. 1992. Flora of the Kerch-Taman Region. Naukova dumka, Kiev, 276 pp. (in Russian) [НовосаА B.B. 1992. ФАора Керченско-Таманского региона. Киев: Наукова думка. 276 с.].

Ovesnov, S.A. 1997. Checklist of the flora of Perm Region. Izdvo Permskogo universiteta, Perm, 252 pp. (in Russian). [Овеснов С.А. 1997. Конспект флоры Пермской об́масти. Пермь: ИзА-во Пермского университета. 252 с.].

Papchenkov, V. G. 2001. Vegetation cover of waterbodies and watercourses of the Middle Volga Region. Yaroslavl', 213 pp. (in Russian) [Папченков В. Г. 2001. Растительный покров водоемов и водотоков Среднего Поволжья. Ярослав $\Lambda$ ь, 213 с.].

Pedregosa, F., G. Varoquaux, A. Gramfort, V. Michel, B. Thirion, O. Grisel, M. Blondel, P. Prettenhofer, R. Weiss, V. Dubourg, J. Vanderplas, A. Passos, D. Cournapeau, M. Brucher, M. Perrot \& É. Duchesnay 2011. Scikit-learn: Machine Learning in Python. Journal of Machine Learning Research: 12:2825-2830.

Pipinys, J. 1963. Vandenplükiniai - Hydrocharitaceae. In: Lietuvos TSR Flora, vol. 2, pp. 105-114, Polotines ir Mokslines Literaturos Leidykla, Viimnus.
Preston, C.D. \& J.M. Croft 2001. Aquatic plants in Britain and Ireland. Brill, Leiden, 365 pp.

Pulević, V. 2005. Materials for the vascular flora of Montenegro. Podgorica. 218 pp.

Ryabinina, Z.N. \& M.S. Knyazev 2018. Manual of the vascular plants of Orenburg Region. Litres, Moscow, 758 pp. (in Russian). [Рябинина 3.Н. Князев М.С. 2018. Опредемитель сосудистых растений Оренбургской области. M.: Litres. 758 c.].

Sapir, Y., A. Shmida \& O. Fragman 2003. Constructing Red Numbers for setting conservation priorities of endangered plant species: Israeli flora as a test case. Journal for Nature Conservation 11:91-107.

Shvanova, V.V. 2006. Hydrocharitaceae. In: Checklist of the flora of Caucasus, vol. 2 (Y.L. Menitskii \& T.N. Popova, eds), pp. 378-379, Saint Petersburg (in Russian). ШШванова В.В. 2006. Hydrocharitaceae // Конспект флоры Кавказа / под реА. Ю.А. Меницкого и Т.Н. Поповой. СПб. Т. 2. С. 378-379].

Skvortsov, A.K. (ed.) 2006. Flora of the Lower Volga, vol. 1. KMK, Moscow, 435 рр. [Фцора Нижнего Поволжья. 2006 / отв. реА. А.К. Скворцов. М.: КМК, Т. 1. 435 с.].

Sobolewska, M. 1977 Roslinnosc interglacjalna ze Stanowic kolo Rybnika na Gornym Slasku. Acta palaeobotanica 18(2): 1-16.

Sosef, M.S.M. 2017. Hydrocharitaceae. In: Flora du Gabon, vol. 50, Anacaridaceae, Hydrocharitaceae, Piperaceae (M.S.M. Sosef, ed.), pp. 52-58. Leiden.

Stepanov, N.V. 2016. Vascular plants of the Ciseenissey Sayans. Krasnoyarsk. 251 pp. (in Russian) [Степанов Н.В. 2016. Сосудистые растения Приенисейских Саян. Красноярск. 252 с.].

Sviridenko, B.F. 2000. Flora and vegetation of Northern Kazakhstan water bodies. Omsk, 196 pp. (in Russian). [СвириАенко Б.Ф. 2000. ФАора и растительность водоемов Северного Казахстана. Омск, 196 с.].

Symoens, J.-J. 2015. Hydrocharitaceae. In: Flore d'Afrique Centrale. Meise. 47 pp.

Symoens, J.-J., J.-F. Villiers \& B. Satabie 1984. Flore du Cameroun. 26: Alismatidées. Flagellariacées. Délégation générale à la recherche scientifique et technique, Yaoundé, 84 p.

Talavera, S., M.J. Gallego \& A. Herrero 2010. Hydrocharitaceae. In: Flora Iberica, vol. 17 (S. Castroviejo Bolibar, ed.), pp. 30-43, Real Jardín Botánico, CSIC2010, Madrid.

Timokhina, S.A. 1988. Frogbit family - Hydrocharitaceae. In: Flora of Siberia, vol. 1 (I.M. Krasnoborov, ed.), pp. 117-119, Nauka, Novosibirsk (in Russian) [Тимохина C.A. 1988. Hydrocharitaceae - Водокрасовые // Фцора Сибири / под реА. И.М. Красноборова. Новосибирск: Наука. T.1. C. 117-119].

Toma, C. 2013. Reproduction of Hydrocharis morsus-ranae taxa in an oxbow lake of the River Vistula. Limnological Review 3:171-178.

Topa, E. 1966. Hydrocharitaceae. In: Flora Reipublicae popularis Romanicae, vol. 1. (T. Savulescu, ed.), pp. 41-48, Academia Reipublicae Popularis Romanicae, Bucureşti.

Uotila, P. 2002. Aquatic flora of Lake Pintele (South Häme, S Finland), with Najas tenuissima. Lutukka 18(4):118-130.

Turis, P., J. Kliment, V. Feráková, D. Dítě, P. Eliáš, R. Hrivnák, J. Košt’ál, R. Suvada, P. Mráz \& D. Bernátová. 2014. Red List of vascular plants of the Carpathian part of Slovakia. Thaiszia - Journal of Botany 24(1):35-87. 
Velichkevich, F.Y. \& E. Zastawniak 2003. The Pliocene flora of Kholmech, south-eastern Belarus and its correlation with other Pliocene floras of Europe. Acta Palaeobotanica 43:137-259.

Vukov, D., G. Anackov \& R. Igic 2003. Rare and protected plants in Zasavica River (Vojvodina, Serbia). In: The VIIth International Symposium Interdisciplinary Regional ResearchISIRR, pp. 43-50, Hunedoara.

Yao, Y.-F., A.A. Bruch, V. Mosbrugger \& C.-S. Li 2011 Quantitative reconstruction of Miocene climate patterns and evolution in Southern China based on plant fossils. Palaeogeography, Palaeoclimatology, Palaeoecology 304:291-307.

Yousefi, M. \& S. Toranj 2015. A preliminary checklist of vascular aquatic plants of Iran. Research Journal of Recent Sciences 4(1):1-8.
Zając, A. \& M. Zając 2001. Atlas rożmieszczenia roślin nacsyniowych w Polsce. Kraków, 280 pp.

Zernov, A.S. 2006. Flora of the Northwest Caucasus. KMK, Moscow, 664 рр. [Зернов А.С. 2006. ФАора Северо-Западного Кавказа. М.: КМК, 664 с.].

Zhu, B., C.C. Ottaviani, R. Naddafi, Z. Dai \& D. Du. 2018. Invasive European frogbit (Hydrocharis morsus-ranae L.) in North America: an updated review 2003-16. Journal of Plant Ecology 11:17-25. 